\title{
Ergative/Absolutive and Active/Stative alignment in West Africa:
}

\section{The case of Southwestern Mande}

\author{
Valentin Vydrin \\ INALCO/CNRS-LLACAN, Paris \\ Museum of Anthropology and Ethnography (Russian Academy of Sciences), \\ St. Petersburg \\ vydrine@gmail.com
}

Valentin Vydrin

Museum of Anthropology and Ethnography

3, University Embankment

St. Petersburg 199034

Russia 


\begin{abstract}
It is usually believed that non-accusative alignment systems are very rare in Africa. A thorough study of the verbal systems of the Southwestern Mande languages (Looma, Mende, Kpelle) has shown that this group is an exception. The Ergative/Absolutive types of argument coding and semantic alignment are observed in these languages mainly in the personal marking on the verbs. In the Liberian dialects of Looma, only stative verbs (belonging to a closed class) show non-accusative encoding, which can be interpreted as an S-split. In Mende, an Active/Stative type of argument indexing is attested on the verbs of an open class. All the verbs in the stative/resultative/perfect construction in Northern Looma and in the stative/resultative/intensive construction in Kpelle display Ergative/Absolutive alignment.
\end{abstract}




\section{Introductory notes ${ }^{1}$}

In survey works dealing with the typology of alignment, it is not uncommon to read statements such as: "[ergative alignment] is represented in languages of various genetic affiliations and on different continents (the only exception so far is Africa, where this construction has not been found)" (Kibrik 2003: 127). The same is often said about semantic alignment (or split-S, or stative-active alignment), which is attested in no African language represented in the Autotyp database (Nichols 2008: 122).

It is true that the claim of Africa as an 'ergative-free continent' is increasingly contested (cf., in particular, [König 2005: 195; Zheltov 2008: 196-211]); while semantic alignmenthas been by Rude (1983) in Looma, a Southwestern Mande language (Southwestern Mande) spoken in Liberia and Guinea by some 300,000 people.

Rude's article became henceforth the sole reference for typologists on this phenomenon in Looma (Dixon 1994: 5-6; Arkadiev 2008: 103-105; Nichols 2008: 134). The main point advanced by Rude, namely the instance of active/stative alignment for the subject pronoun series in Looma, is valid. However, a number of Rude's interpretations are unsupported by the evidence, especially those concerning the details of the mechanism of the initial consonant alternation of the verbs and the analysis of the pronominal paradigms, and these are key points in the analysis of the Looma situation. His misinterpretations were inherited by the authors of later typological studies. Among numerous cases, it can be mentioned that in Dixon's (1994) book on ergativity, Looma was mentioned as the only Niger-Congo language where ergativity had been attested, although of a rather unusual type: "One could almost say that Loma has 'phonological' (rather than morphological or syntactic) ergativity" (Dixon

\footnotetext{
${ }^{1}$ This study was carried out with the project "Field study of Mande languages of Guinea and Côted'Ivoire", supported by the grant A-07-2011 of the Foundation for Fundamental Linguistic Studies.
} 
1994: 5-6). In reality, there are no reasons for identifying 'phonological ergativity' in this language.

In the present paper, I shall first analyze the situation in Liberian Looma, the variety dealt with by Rude (1983), and advance an adequate interpretation of its argument coding system.

This analysis will be preceded (Section 2) by information concerning the mophophonological and morphosyntactic peculiarities of Looma. These features, in particular the consonant alternation and the person-marking paradigms, are very similar to those in the other Southwestern Mande languages (SWM); therefore, Looma will serve to exemplify the other languages as well.

The argument coding manifests itself in this language variety in the system of personal marking (Section 3): $\mathrm{A}$ and $\mathrm{S}_{\mathrm{a}}$ are encoded by pronominal auxiliaries ('Pronominal Predicative Markers' $)^{2}$, and $\mathrm{S}_{\mathrm{o}}$ and $\mathrm{O}$ by personal indexes on the verb. So, in Looma ${ }^{3}$ :
(1) $E^{\prime}$
(’́-)páa.

3SG.BAS 3SG-kill

'He killed him'.

${ }^{2}$ The term 'Personal Predicative Marker' (PPM), or (to make it look more familiar to nonspecialists in Mande languages) 'pronominal auxiliaries' is preferable to 'person-inflected predicative markers/auxiliaries' for the reasons expounded in (Vydrin 2010: 391-392). The term 'predicative marker' is traditionally used in Mande studies as an equivalent to 'auxiliary'. PPM/pronominal auxiliaries originate from an amalgamation of subject personal pronouns with TAM-polarity markers (not morphologically attached to the verb).

${ }^{3}$ In what follows, abbreviations are used in the same way as in (Dixon 1994; Nichols 2008; Bickel $\&$ Nichols 2009): A for the agent-like argument of a bivalent verb; $S$ for the argument of a monovalent verb; $\mathrm{O}$ for a patient-like argument of a bivalent verb (for the purposes of the current paper, there is no need to distinguish between objects of monotransitive and ditransitive verbs); $\mathrm{S}_{\mathrm{a}}$ for a $\mathrm{S}$ coded as $\mathrm{A} ; \mathrm{S}_{\mathrm{o}}$ for a $\mathrm{S}$ coded as $\mathrm{O}$. 
(2) (̉́-)gwálá.

3SG-be.big

'He is big'.

It turns out that, with respect to the distribution of the $\mathrm{S}_{\mathrm{a}}$ and $\mathrm{S}_{\mathrm{o}}$ (nominative/accusative and ergative/absolutive) features, the Liberian Looma dialects display at least two different types of split: (a) according to the verbal semantics (which results in a semantic alignment), and (b) according to the TAM and polarity. Only verbs with the qualitative semantics (a closed class) have their $\mathrm{S}_{\mathrm{o}}$ marked in the same way as $\mathrm{O}$, and only in the affirmative 'stative aspect'. Both splits follow well-known typological tendencies (cf., in particular, Dixon 1994: 70-110).

In the Northern Looma dialects spoken in Guinea (Luloma, Woi-Balagha), the situation is different: instead of two splits, there is a single split, according to the TAM and polarity. Any $\mathrm{S}$ is indexed on the verb (i.e., it is encoded in the same way as $\mathrm{O}$ ) in the resultative construction. The Northern Looma ergative system is discussed in Section 4.

Section 5 deals with the aspect-split system of Kpelle, where any intransitive verb is $\mathrm{S}_{\mathrm{o}^{-}}$ indexed in the stative-resultative-intensive construction; unlike in Northern Looma, this construction is incompatible with transitive verbs.

The Mende data is discussed in Section 6. In this language, the S-split is different from the other languages of the group. The list of Mende $\mathrm{S}_{\mathrm{o}}$-verbs is open and includes only patientive verbs (along with P-labile verbs ${ }^{4}$ in their intransitive use). The S-split type differs

\footnotetext{
${ }^{4}$ Lability is the capacity of a verb to appear as transitive or intransitive without modifying its morphology. Two major types of labile verbs can be distinguished: P-labile, whose intransitive subject corresponds to the direct object of the respective transitive construction (cf. I shaked him by the shoulders. - He shakes with cold), and A-labile, whose subject remains the same in transitive and intransitive constructions (cf. I eat an apple. - I eat). Many Mande languages have extremely productive P-lability.
} 
from Liberian Looma in some important details: a) the semantics of the $\mathrm{S}_{0}$-verbs in Mende is not restricted to the qualitative verbs; b) the aspectual meaning of the construction with $\mathrm{S}_{0^{-}}$ verbs is stative/resultative (rather than just stative), and c) its negative counterpart can assume a $\mathrm{S}_{\mathrm{o}}$ marking (which erodes the 'polarity split' typical of the other SWM languages) ${ }^{5}$.

In Section 7, the semantic nature of the S-split in Liberian Looma is discussed. Special attention is paid to the semantic role of the sole argument of a $\mathrm{S}_{0}$-encoded verb; this role is characterized as 'Holder of a Property'.

In Section 8, the emergence of the non-accusative alignment in Southwestern Mande is discussed, with special attention paid to the etymology of the suffixes of the stative construction in Looma. $\mathrm{S}_{\mathrm{o}}$-encoding in the stative/qualitative construction is common to all the languages of the group, while other contexts vary from one language to another. For this reason, the stative/qualitative construction can be regarded as original, and the other contexts as derived from it.

\section{SWM morphophonology and sentence structure: Looma}

\subsection{Consonant alternation}

${ }^{5}$ The data from Loko, another SWM language, is not discussed in this paper because of its scarcity. I would just mention that this language seems to be similar to Mende in respect of its alignment model. 
Table 1. Consonant alternation in Looma (simplified) ${ }^{6}$

\begin{tabular}{|l|l|l|l|l|l|l|l|l|l|l|l|l|}
\hline strong grade (preceded by $(\eta))$ & $\mathrm{p}$ & $\mathrm{b}$ & $\mathrm{t}$ & $\mathrm{d}$ & $\mathrm{k}$ & $\mathrm{g}$ & $\mathrm{kp}$ & $\mathrm{kW}$ & $\mathrm{gw}$ & $\mathrm{f}$ & $\mathrm{s}$ & $\mathrm{z}$ \\
\hline weak grade (not preceded by $(\eta))$ & $\mathrm{v}, \beta, \mathrm{w}$ & $\mathrm{v}, \beta, \mathrm{w}$ & $\mathrm{l}$ & $\mathrm{l}$ & $\mathrm{\gamma}, \mathrm{W}$ & $\mathrm{\gamma}, \mathrm{w}$ & 6 & $\mathrm{w}$ & $\mathrm{w}$ & $\mathrm{v}, \mathrm{B}$ & $\mathrm{z}$ & $\mathrm{y}$ \\
\hline
\end{tabular}

${ }^{6}$ Dialectal variations in the consonant alternation and in the conditioning of the weak alternates by subsequent vowels are not represented in the Table. These details (cf. Vydrin 1987: 20-21; Vydrin 2006: 100-108) do not affect the analysis. 
Looma, like any other SWM language ${ }^{7}$, is characterized by the phenomenon of wordinitial consonant alternation (Table 1). An explanation of the mechanism of this consonant alternation is indispensable for understanding the functioning of the personal prefixes.

The consonant alternation is attested in all syntactic contexts for all major word classes, and is diachronically explained by the presence or absence of a preceding nasal syllabic element, ${ }^{*} \eta$. This element has vanished in modern Looma, leaving a floating feature (shown as a $\eta$ in brackets $)^{8}$.

The Proto-SWM nasal sonant could have been either a word-final element (belonging to the word stem; it probably possessed a tone of its own), or a personal pronoun preceding a postposition, the head of a NP or VP; in the latter case, it was undoubtedly a tone-bearing unit $\left({ }^{*} \grave{\eta} 1 \mathrm{SG},{ }^{*} \not{\eta} 3 \mathrm{SG}\right)$. On the basis of the $3 \mathrm{SG}$ pronoun ${ }^{*} \not$, a prefixed referential article emerged at the Proto-SWM level.

In Looma, if preceded by a floating ( $\eta)$, a word-initial consonant maintains its 'strong' alternation grade (example 3a); otherwise, it undergoes lenition and acquires a 'weak' alternation grade (example 3b; in both examples, we have one and the same P-labile verb

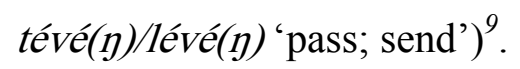

${ }^{7}$ The initial consonant alternation in SWM is a popular topic among linguists, and about two dozen publications can be listed in connection with it. For a detailed bibliography and analysis of this phenomenon, see (Vydrin 2006: 99-156); an earlier (and less advanced) version of the analysis is available in English: (Vydrin 1989b).

${ }^{8}$ As was correctly remarked by an anonymous reviewer, in a synchronic analysis of Looma there is no evidence for positioning a floating nasal velar, and in the synchronic descriptions I usually represent the floating feature as $(g)$. However, in the current paper it is marked as $(\eta)$ for the sake of uniformity with the representation of similar floating features in other SWM languages.

${ }^{9}$ The two-level tonal system of Looma is characterized by a complicated set of rules, so that the lexical tones of words are sometimes extremely difficult to identify; these rules vary from one dialect to another. In Sadler's publications (1951, 1949/2006), the surface realizations of tones are marked; for a tentative outline, only partly successful, of the tonal system (based on Sadler's data), see 
Examples:

(3a) Gà (ý-)tévé(g)/tévé/

\section{SG.FUT 3SG-pass/send}

'I will send him'.

(3b) Gà lévé(ク)/lévé/

1SG.FUT pass/send

'I will pass'.

In word-final position, the floating ( $\mathrm{y}$ ) has three manifestations:

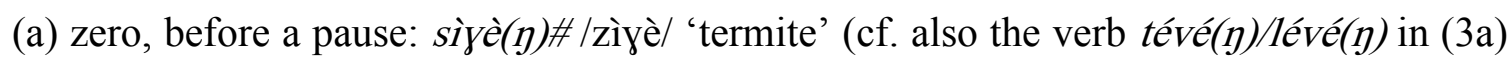
and (3b));

(b) $-g$-, if followed by a vocalic suffix (such as a definite article $-i$ or indefinite plural marker - $a$ ): $\mid$ sìyè(y)-i $\mid \rightarrow$ /zìyègì/ 'the termite';

(c) the strong alternation grade of the initial consonant of the subsequent word: $\mid(\mathfrak{y}$-)dàse(y)-i $\mid \rightarrow$ /dáségí/ 'his-name’ (cf. è-làsègì 'your.SG-name’ where the initial consonant of the noun stem has the weak alternation grade, since it is not preceded by the floating (y)). Cf. also the example (4a), where the initial consonant of the noun $k p j k p \grave{\jmath}(\eta) / 6 j k p \grave{\jmath}(\eta)$ 'chair' is strong because of the preceding referential article (ý), and the initial consonant of the

(Vydrine 1989a). An attempt to formulate tonal rules in noun phrases was undertaken by Dwyer (1973) for Liberian Looma. A more comprehensive study of the tonal system of Looma (for the WoiBalagha dialect in the Macenta area, Guinea) was carried out by Mishchenko (2009). In what follows, the tonal marking of the sources of the data is retained. In fact, only grammatical tones, including the tones of pronominal prefixes and pronominal predicative markers, are relevant for the current study.

The segmental orthography of different sources has been unified by me. 
adjective $g$ wàlà/wàlà 'big' is strong because it is preceded by the stem-final ${ }^{*}-\eta$ of the head noun:

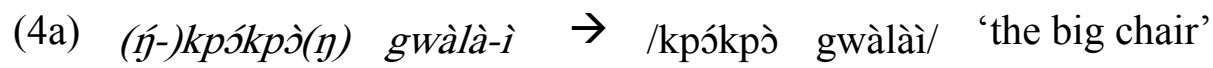
REF-chair big-DEF

On the other hand, in sentence (4b) the noun has no floating $(-\not)$ ) at the end, and the subsequent adjective begins with a weak grade consonant:

(4b) (ý-)péle gwàlà-ì $\rightarrow$ /péle wàlài/ 'the big road'

REF-road big-DEF

In what follows, the floating nasal velar will be represented in brackets, so that the NP in

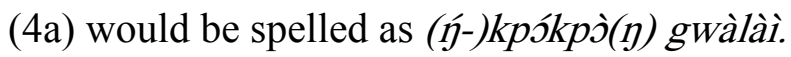

\subsection{Sentence structure, pronominal prefixes and pronominal auxiliaries in SWM (exemplified by Looma)}

The consonant alternations are crucial for the transcategorial personal prefix ${ }^{10}$ system that constitutes non-accusative alignment as exemplified in the introductory examples. Their paradigm is given in the Table 2 (from Vydrin 1987: 34). The 1SG and 3SG forms are represented by a floating nasal element with respectively low and high floating tones (see 2.1 for more details).

\footnotetext{
${ }^{10}$ In previous works on Looma, including mine, the elements in question were most often regarded as autonomous words. However, their inseparability from the head word and the fusion of the 1SG and 3SG forms with the head word are strong evidence for their prefixal status. Cf. a similar interpretation of analogous elements in Mende by Creissels [2005: 53].
} 
Table 2. Pronominal prefixes

Vekema dialect (Guinea) Northern dialects (Guinea) Liberian dialects

\begin{tabular}{|c|c|c|c|c|c|}
\hline & Sg. & P1. & $\mathrm{Sg}$. & Pl. & Sg. \\
\hline 1 & $(\grave{\eta}-)$ & gé- & $(\grave{\eta}-)$ & $g I^{-}$ & $(\grave{\eta}-)$ \\
\hline 1 inclusive & - & dé- & dé- & àdé- & - \\
\hline 2 & $\grave{e}-$ & $\grave{a}$ & $\grave{e}-$ & Wò- & $\grave{e}-$ \\
\hline 3 & $(\not{y}-)$ & té- & $\left(\eta^{-}\right)$ & $t i ́-$ & $\left(\eta^{-}\right)$ \\
\hline
\end{tabular}


In a dynamic verbal sentence, the personal prefixes may substitute for a direct object by indexing it on the verb (5), an oblique object by indexing it on the postposition (6), or a nominal modifier in a genitive-like NP by indexing it on the head noun (7) ${ }^{11}$. Let us observe that their position in the sentence is the same as that of the NP they substitute, which is explained by their recent morphologization:

(5) Tá

(í-)kává-zù.

3PL.IPFV 3SG-bend-IPFV

'They are bending it' (Sadler 1949/2006: 34).

(6)

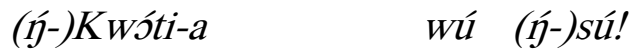

REF-stone-PL.INDEF put 3SG-in

'Pour stones into it!' (Sadler 1949/2006: 41).

(7) (ì-)dèe

1SG-mother

'my mother' (Vydrin 1987: 39).

SWM languages are characterized by a fixed word order. A verbal sentence (containing a dynamic verb) normally has the following structure:

(A) - AUX - (O - ) V (Obl) for transitive verbs,

(S) - AUX - V (Obl) for intransitive verbs.

It should be emphasized that in Mande languages only the pre-verbal position is reserved for a direct object. Any post-verbal NP, whatever its semantic role, cannot be regarded as a direct object (for the argumentation see, among numerous other publications, Nikitina 2009).

${ }^{11}$ Therefore, in the terms of (Bickel \& Nichols 2009), we have in SWM a $\mathrm{S}=\mathrm{O}=\mathrm{G}$ type. However, in the present paper I shall limit discussion to the coding of the core arguments. 
Subsequently, any verb is intransitive which is not preceded by a direct object NP or (in SWM) not indexed for a direct object by a pronominal prefix.

The AUX position is occupied by auxiliaries ${ }^{12}$ expressing the person and number of the subject of the sentence (in what follows, these auxiliaries will be referred to as 'pronominal auxiliaries') and also the tense-aspect-modality-polarity (together with verbal suffixes and modifications of verbal tones). In other words, the TAM-polarity meanings are expressed by the choice of an auxiliary, a verbal suffix and, in certain cases, also by a modification of verbal tones.

There are several series of pronominal auxiliaries in Looma. Two of them are represented in the Table 3 (for Liberian Looma) ${ }^{13}$.

\footnotetext{
${ }^{12}$ These auxiliary elements were traditionally regarded as subject personal pronouns. In fact, there are strong reasons to regard them as auxiliaries ('predicative markers' in the Mandeist linguistic tradition); for the argumentation see (Vydrin 2010). An interpretation of similar elements in Mende as 'subject markers' (rather than 'subject pronouns') was suggested by Creissels (2005: 53).

${ }^{13}$ There are several more sets, but for purposes of the current presentation, these two are sufficient. For a survey of the 'subject pronouns'/pronominal auxiliaries in different Looma dialects, see (Vydrin 1987: 32-42). See also (Heydorn 1971: 84-85; Prost 1967: 38-45; Sadler 1949/2006). For a detailed study of the pronominal auxiliaries in the northern Guinean dialect Woi-Balagha, see (Mishchenko 2010). For a comparative analysis of the pronominal system of SWM (including the pronominal auxiliaries), see (Babaev 2010).
} 
Table 3. Two series of pronominal auxiliaries in Liberian Looma

'Basic' series

gè

1

$1+2$

2

3
Sg. $\quad$ Pl. $(+3)$
Sg. $\quad$ Pl. $(+3)$

gé

dé

Wò

té
'Imperfective' series

$\mathrm{Sg}$.

Pl. $(+3)$

gà

gá

$-$

dá

yà

Wà

é/Ø

tó/ kà/yà

tá 
A pronominal auxiliary is obligatory, even if the Subject position is filled:

(8) Wolowolo ze sue-tiye té Jénì yepe-ze.

formerly in animal-PL.DEF 3PL.BAS PST speak-IPFV

'In the olden days, animals used to talk' (Vydrin 1987: 73).

At the same time, the Subject position may remain vacant (as the pronominal auxiliary does not represent an NP, it does not fill the Subject slot):

(9) Té (ý-)kúló (í-)pélé wù.

3PL.BAS 3SG-exit ART-house under

'They led him out' (Vydrin 1987: 51).

The variants of the 3SG Imperfective auxiliary, tó and kà/yà, are distributed as follows:

tó appears in null-subject sentences (10a), while kà/yà appears if the Subject is explicitly expressed, i.e., if it is not a null-subject sentence (cf. $10 \mathrm{~b}$ and $10 \mathrm{c}$, examples are from Sadler 1949/2006):

(10a) Tó vàa-zù.

3SG.IPFV come-IPFV

'(S)he is coming'.

(10b) (ý-)Nú tà yà vàa-zù.

REF-person certain 3SG.IPFV come-IPFV

'A person is coming'.

(10c) (ý-)Kpó(ク) ká vàa-zù.

REF-crowd 3SG.IPFV come-IPFV

'A crowd is coming'. 
As for the variants of the 3SG Basic auxiliary, the zero allomorph appears when the Subject NP is non-null (11b), and the allomorph é is used in null-subject sentences (11a):

(11a) É lóbá-ni Folomo ma...

3SG.BAS shout-PST Folomo at

'(S)he shouted at Folomo...'

(11b)

(’̉-)Zúnu-i $\quad$ lóbá-ni Folomo ma...

REF-man-DEF 3SG.BAS shout-PST Folomo at

'The man shouted at Folomo...'

One could suggest a different interpretation: in (11a), é is a (pronominal) subject; in (11b), zúnui is a (nominal) subject, and there is no need to postulate a zero pronominal auxiliary in (11b). However, this interpretation cannot explain the obligatory presence of té in the auxiliary position in a phrase with a pluralized subject NP $(11 \mathrm{c} \text {, and also } 8)^{14}$ :

(11c)

(í)Zúnu-i-tìe té lóbá-nì Folomo mà...

REF-man-DEF-PL 3PL.BAS shout-PST Folomo at

'The men shouted at Folomo...'

The non-zero variant of the 3SG Basic auxiliary, é, appears also in sentences with a topicalized or relativized subject $(12,13)$ :

\footnotetext{
${ }^{14}$ This fact seems to be crucial in the definition of the elements in question in Looma as pronominal auxiliaries, rather than subject pronouns (for further arguments, see Vydrin 2010; Hachaturyan 2010). It is evident that historically kà/yà was a non-pronominal auxiliary which has merged with the subject pronouns in the imperfective constructions. The interpretation of tó and kà/yà as allomorphs is strictly synchronic.
} 
(12)

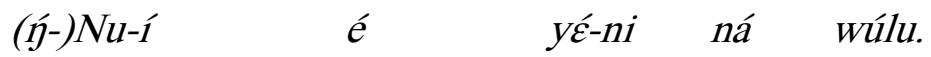

REF-human-DEF 3SG.BAS be-PST there behind

'The person who stayed behind' (Sadler 1949/2006: 33).

$\begin{array}{lllll}\text { (13) } & \text { Go } & \text { (ýla } \text { baya-i } & \text { mi-a. } \\ \text { 3SG.AUT also } & \text { 3SG.BAS } & \text { REF-rice-DEF } & \text { eat-PRF }\end{array}$

'He also has eaten the rice' (Koima dialect, Wilhoit 1999: 72).

Apart from the personal auxiliaries, there are several sets of 'true' personal pronouns which appear in the NP positions and differ from each other in respect of their case and communicative / pragmatic status.

\section{The Active/Stative strategy in Liberian (Western) Looma: Stative (qualitative)} verbs

The situation in (Liberian) Looma, as formulated by Arkadiev (2008: 103) is as follows: "If we turn to monadic predicates, we find that most of them require 'Subjective' encoding of their sole argument, identical to the A of dyadic predicates ...; however, there is a class of predicates, namely stative verbs, whose sole argument is encoded as the $\mathrm{P}$ of dyadic predicates".

Arkadiev's analysis (based on Rude's) is correct in principle; however, it lacks details which may be important for the definition of the alignment type of Liberian Looma. One of the major points here is the status and behavior of the 'stative verbs': let us scrutinize them.

This class of lexemes in Liberian Looma is regarded by certain authors (Heydorn 1971; Sadler 1949/2006) as 'adjectives', and by some others (Dwyer, Bodegie, Baque 1981; Vydrin 1987) as verbs. Here is the list, according to (Vydrine 1987: 47-48), however incomplete it may be ${ }^{15}$ :

\footnotetext{
${ }^{15}$ Only forms taken from Liberian dialects are given here.
} 
bi 'be heavy';

bools 'be big; be numerous';

dèi 'be wet, be cold';

fila 'be hot; be dangerous';

gola 'be big; be old; be important';

kóle(g) ‘be white’;

$\operatorname{kooza}(\eta)$ 'be high, be long, be remote’;

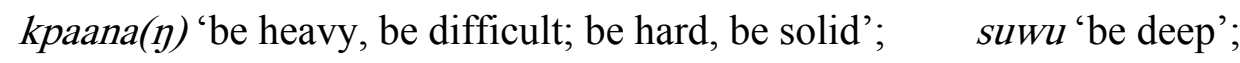

kpa6a 'be strong';

kpene 'be small';

kpoda 'be bitter';

There are three syntactic positions, crucial for our analysis, in which these lexemes currently appear (examples from Sadler 1949/2006):

- as a nominal modifier (i.e., in a position typical for the adjectives):

(14a) (í-)gúlú nòwò-ì-tì̀

REF-stick dirty-DEF-PL

'the dirty sticks';

- as the main predicate in a sentence expressing a state or a quality (a typical position for the stative verbs / predicative adjectives):

(14b) (ñ)-Gúlúi-í nว̀wò-vè.

REF-stick-DEF be.dirty-STAT kpóe 'be red; be ripe';

kpuo 'be short';

nono 'be weak';

$n \tilde{\varepsilon}^{\prime}$ be sweet';

nowo 'be dirty';

nֵٌ 'be bad, be ugly’;

$p a(\eta)$ 'be good';

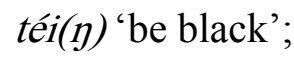

$\operatorname{tama}(\eta)$ 'be numerous’, etc. 
'The stick is dirty';

- as a dynamic (transitive or intransitive) verb, i.e. a verb with an inchoative meaning (entering into a state):

(14c) Gà (ý-)bóá nòwò.

1SG.FUT REF-knife dirty

'I will dirty a knife'.

(14d)

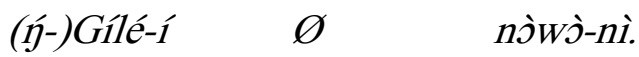

REF-dog-DEF 3SG.BAS dirty-PST

'The dog became dirty'.

(14e) $E^{\prime} \quad$ nว̀wว̀-nì.

3SG.BAS dirty-PST

'It became dirty'.

Are we dealing here with two or three different lexemes (related by conversion) or just one lexeme (fulfilling three different syntactic functions)? Undoubtedly, it is the stative verb/predicative adjective function (14b) which represents the main point of discord. Let us consider this function in more detail.

The stative verbs have two morphologically marked forms, Stative Past and Stative NonPast; these forms are not available for dynamic verbs. The non-past marker has two allomorphs: $-v \varepsilon$ for stems ending in a vowel (15), and $-\varepsilon$ for stems ending in a floating $(-\eta)$, in which case the floating element is attached to the end of the root in the form of - $g$ - (16). Both these forms are used without a copula ${ }^{16}$ :

${ }^{16}$ Forms of these markers among the Looma dialects are given in Table 9 (Section 8.1). According to (Mishchenko 2009: 11), in the Woi-Balagha dialect the lexical tone of a stative verb never manifests itself on its stem; it appears instead on the suffix. 
(15)

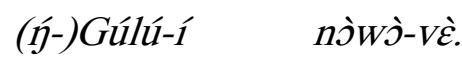

REF-stick-DEF be.dirty-STAT

'The stick is dirty'.

(16) (ñ-)Gúlú-í bàanàg-é.

REF-stick-DEF be.hard-STAT

'The stick is hard' (Sadler 1949/2006: 31).

The past marker is $-a i$ for any stem type in Liberian Looma, and the stative verb is optionally followed by the auxiliary $\mathrm{f}^{1 / 7}$ :

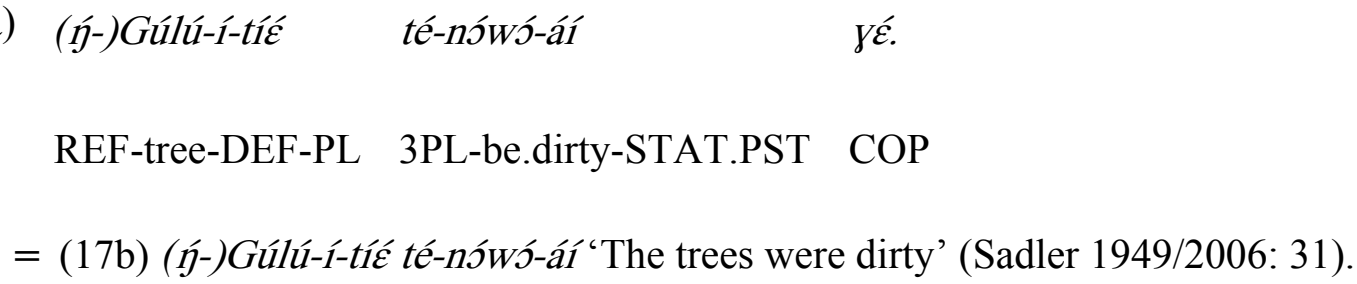

The diagnostic context for the argument-marking pattern is the situation where the sole argument is represented by a $3 \mathrm{SG}$ or $1 \mathrm{SG}$ pronominal element, in the absence of a coreferent NP (18a, b):

(18a) (ந́-)Kpádí-vé.

3SG-be.hot-STAT

'It is hot'.

(18b)

(ท́-)Kpádí-áí. $\quad$ gé.

3SG-be.hot-STAT.PST COP

${ }^{17}$ Sadler makes no comment about the function of this auxiliary, he simply provides two phrases in question, (17a) and (17b), with identical translations. In (Dwyer, Bodegie, Baque 1981: 98), the Past Stative form with the $-a i /-\varepsilon i$ suffix is interpreted as nominal (without detailed analysis), and the copula is $\mathrm{y}^{\mathrm{a}}$ 
'It was hot' (Sadler 1949/2006: 31).

The strong grade of the initial consonant alternation is indicative of the presence of the floating feature ( $\left(\eta^{-}\right)$which can be nothing other than the $3 \mathrm{SG}$ pronominal prefix, i.e. a $\mathrm{S}_{\mathrm{o}}{ }^{18}$ (cf. (14e) where the sole argument is a $\mathrm{S}_{\mathrm{a}}$, for it is coded by a pronominal auxiliary):

Therefore, Rude's (1983) interpretation of the Looma strategy as 'Active/Stative' is correct on this point in principle, although it is misleading ${ }^{19}$ or vague on some important details.

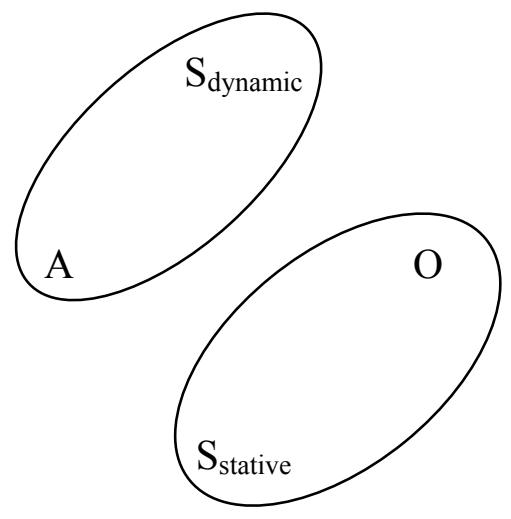

${ }^{18}$ A suggestion by an anonymous reviewer that the stative verb in (18a) might be a 0 -argument impersonal is invalidated by two arguments:

(1) the 3SG is clearly indexed on the verb by a floating nasal ( $\eta$ ): in the absence of a floating nasal element, the stative verb would have the weak grade initial consonant ( ${ }^{*}$ Gadi-ve, ${ }^{*}$ badi-ai ${ }^{\varepsilon} \varepsilon$ ). As was explained in Section 2.2, the non-segmental 3SG morpheme 'floating nasal + floating high tone' is perfectly integrated into the paradigm of the pronominal prefixed markers;

(2) in SWM and South Mande, the impersonal meaning is normally expressed by a dummy 3PL pronominal element, and not by the $3 \mathrm{SG}$ subject pronoun.

Therefore, there are no reasons to explain the emergence of semantic alignment in Looma through grammaticalization from transimpersonal verbs (as described in Donohue 2008: 67-71; Malchukov 2008; Mithun 2008).

${ }^{19}$ In his examples (98), (99) and (102), Rude provides sentences with 1PL (exclusive) personal markers, which are not distinctive, because 1PL.EXCL forms in the Basic auxiliary series and in the personal prefix paradigm are homonymic. The only diagnostic forms which distinguish between both sets are $1 \mathrm{SG}$ and $3 \mathrm{SG}$. 
However, any stative verb can be also used dynamically, thus expressing the sense of the 'coming into being' of the state. In this case, it assumes the 'active' paradigm and is conjugated with pronominal auxiliaries, rather than with pronominal prefixes (ex. 14c, 14d, 18c):

(18c) $E^{\prime}$

Gádí-á.

3SG.BAS hot-PRF

'It has become hot'.

Now we can return to the question raised above: do a stative verb and a corresponding dynamic verb (like kpádi/6ádi 'be hot' and kpádi/bádi 'become/make hot') represent one and the same lexeme? If we treat them as one lexeme, the paradigm of stative verbs is just a subsystem of the verbal paradigm. Two other possibilities are: to consider stative verbs as a separate part of speech (syntactic category), or to include them into the class of adjectives, i.e., to regard them as predicative adjectives.

An argument that may be crucial here is the formation of a regular negative stative construction (examples from Heydorn 1971: 87-88):

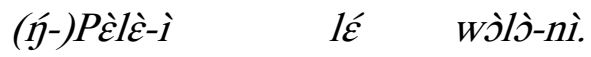

REF-house-DEF NEG be.big-PST

'The house is not big'.

(20)

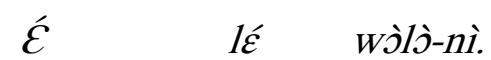

3SG.NEG NEG be.big-PST

'It is not big'.

In a null-subject sentence we find the $3 \mathrm{SG}$ negative auxiliary $\varepsilon$, and the verb is provided with the suffix $-n i . \varepsilon$ is used, together with the marker $l \varepsilon$, in all negative verbal TAM 
constructions (only Prohibitive has a different marker); the suffix $-n i$ is the regular past marker of dynamic verbs, cf. (Heydorn 1971: 90-92):

(21) $\varepsilon$

lé (ì-)tòlì-nì.

3SG.NEG NEG 1SG-call-PST

'He has not called me'.

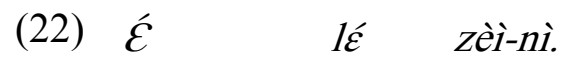

3SG.NEG NEG sit-PST

'(S)he is not sitting'.

This means that the negative construction with stative verbs:

(a) displays a $\mathrm{S}_{\mathrm{a}}$ (nominative/accusative) alignment, and

(b) uses the same morphological means as 'dynamic' constructions.

The morphosyntax of the negative construction with the stative verbs shows that it is integrated into the verbal TAM paradigm. This is a strong argument to treat the stative and dynamic verbs in Liberian Looma as one syntactic category, 'Verb'20, and the S-split in Liberian Looma as an instance of semantic alignment (cf. Donohue 2008: 34). Verbs with inherently dynamic meaning cannot be used with $\mathrm{S}_{\mathrm{o}}$ (i. e., in constructions with a nonnominative alignment $)^{21}$, the stative construction is therefore only possible for lexemes with

\footnotetext{
${ }^{20} \mathrm{Cf}$. the situation in another Mande language, Bamana, where a morphosyntactic analysis results in the establishment of three different parts of speech: (dynamic) verb, qualitative verb, and adjective (Vydrine 1999). I am not going to analyze here the problem of the correlation between adjectives and verbs in Looma, which requires much more detailed data than is available today on the regularity or irregularity of this correlation.

${ }^{21}$ It should be mentioned that Looma has at the same time a $S_{a}$ stative construction for inherently dynamic verbs (mainly for verbs of spatial position). This construction is illustrated by example (22); its affirmative counterpart is Tóá zè̀̀-nì. '(S)he is sitting'.
} 
an inherently qualitative meaning. In other words, the usage of verbs in these constructions is semantically conditioned ${ }^{22}$.

In Bandi, a Southwestern Mande language spoken in Liberia, to the west of the Looma area (and much more poorly documented than Looma), the verbs seem to follow the same Ssplit pattern as their counterparts in Liberian Looma. (Heydorn 1940/41; Anon. n. d.).

\section{Ergative strategy in Northern Looma}

\subsection{Perfect/resultative/stative}

In the northern dialects, such as Luloma and Woi-Balagha ${ }^{23}$, the stative construction is formed in a similar way to the Liberian Looma model, although the morphology is slightly different. So, in Luloma, the verbal suffix is -ave/-dave: (ந́-)tei-dave 'it is black', (ந́-)pag-ave 'it is good' (Prost 1967: 83; for the forms in other dialects, see Table 9). What distinguishes these dialects from the Liberian ones is the $S_{o}$ coding in the perfect/resultative construction for the dynamic verbs (formed with the same suffix, -ave, or $-v e^{24}$ ). Therefore, in this construction, A is coded by the pronominal auxiliaries, while $\mathrm{S}$ for any kind of verb is encoded by pronominal prefixes on the verb.

(23) $\quad ́$

ani yaa-ve.

${ }^{22}$ In Mithun's terms (1991), this system is based upon a distinction of 'lexical aspect'. In fact, the Liberian Looma system is strikingly close to the Guaraní system which can be "identified as activestative" (Mithun 1991: 514).

${ }^{23}$ For Luloma, the data are from (Prost 1967), together with my own field materials; for WoiBalagha (a central-northern dialect taken as basic for the creation of a written norm for Guinean Looma), see (Mishchenko 2010) and other works by the same author (published mainly in Russian). The same alignment type seems to exist in central dialects of Guinean Looma, among them a central Guinean dialect, Koima, dealt with by Wilhoit in her MA dissertation (1999), although the problem of alignment is not addressed by this author directly.

${ }^{24}$ Most probably, the element $-a$ is identical with the perfect participle suffix. If this is true, the form -ave is a combination of two suffixes which will be glossed as PRF and RES. 
3SG.BAS thing see-RES

‘(S)he has seen something' (Prost 1967: 35).

(24) $E^{\prime}$

$$
\text { (í-)ké-a-ve gà pago. }
$$

3SG.BAS 3SG-do-PRF-RES with good

'He has done it well'.

(25)

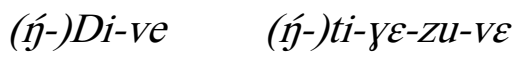

\section{SG-go-RES REF-field-do-in-LOC}

'He has gone to do farmwork' (Prost 1967: 75).

In (23) and (24), the subjects of transitive verbs are coded by a 3SG pronominal auxiliary é. In (25), the verb di/li 'to go' is intransitive, and its sole argument is coded by the nonsegmental 3SG pronominal prefix (a floating nasal element and a floating high tone, see Table $3)$.

The verbal marker and the argument marking strategy in the resultative construction in Luloma are identical to those for the stative construction in Liberian Looma (see above). In other words, in this dialect there is no need to formally distinguish a verbal class of stative verbs from the dynamic verbs; we have one resultative/stative construction which allows verbs to realize their stative or resultative meaning, depending on their semantics. So, the Northern Looma resultative/stative construction shows a true Ergative/Absolutive strategy: the sole argument of any intransitive verb is encoded by a pronominal prefix, i.e. in the same way as the direct object of a transitive verb, while the Agent of a transitive verb is encoded by the pronominal auxiliaries.

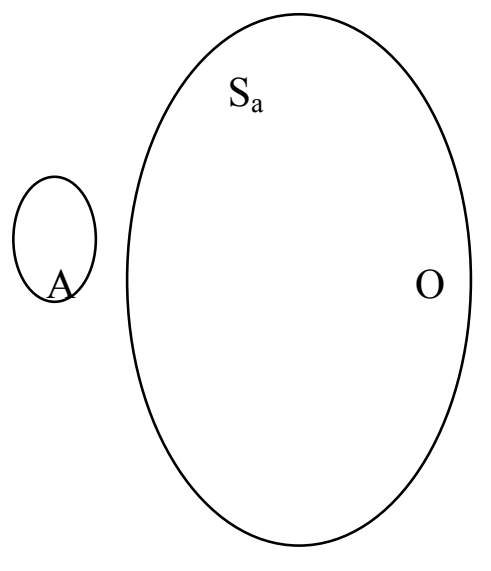


This is a typical instance of split-ergative morphological alignment: it is ergative in the resultative/stative construction, and nominative/accusative in the other TAM constructions.

\subsection{Ergative strategy in relative clauses.}

The same ergative alignment (the $\mathrm{S}_{\mathrm{o}}$ prefixal coding of the sole argument on intransitive verbs $(26,27)$ and the pronominal auxiliary encoding for the agent-like argument of a bivalent verb (28)) is attested in Luloma in relative clauses for the perfect/resultative aspect, marked on the verb by a suffix $-i \sim-\varepsilon i$ (examples from Prost 1967: 99):
(1’-) $S a b a-i_{i}$
$[(\mathfrak{y}-) d a-\varepsilon i$
(ந̄́-)má,]

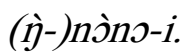

REF-mat-DEF 3SG-lie-REL.RES 3SG-on 1SG-property-DEF

'The mat on which he is lying is mine'.

(27)

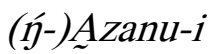
$\left[\left(\mathfrak{y}^{-}\right) d \dot{i}-\varepsilon i,\right]^{\prime}$
(ì-)bazile-i
ve.

REF-woman-DEF 3SG-go-REL.RES 1SG-different.sex.sibling-DEF COP

'The woman who has gone is my sister'.

(28)

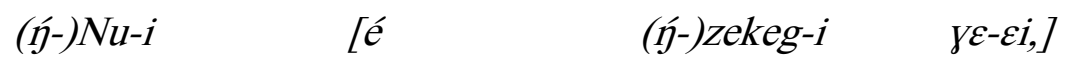

REF-human-DEF 3SG.REL.BAS REF-work-DEF do-REL.RES

tówà

mini?

3SG.NPST where

'The person who has done the work, where is he?'

In the other TAM constructions, the nominative/accusative strategy is applied (the relative personal auxiliaries follow the Subject NP both with transitive and intransitive verbs): 
(29)

$(\hat{y}-)$ Guli-i [é $\quad$ lo-ni, $] \quad(\hat{j}-)$ gbay- $i \quad$ ve.

REF-tree-DEF 3SG.REL.BAS fall-PST REF-ceiba-DEF COP

'The tree that fell is a ceiba'.

\section{Ergative alignment in Kpelle}

In Kpelle, just like in Looma, A (subject of a transitive verb) cannot be indexed on verb by a personal prefix. Otherwise, the situation is different to that in both Liberian and Northern dialects of Looma ${ }^{25}$. Unlike in Liberian Looma, $\mathrm{S}_{\mathrm{o}}$ coding is not restricted to the "qualitative verbs', but is permitted for virtually any verb of the language. As a result, the aspectual semantics of the $\mathrm{S}_{0}$-coded construction varies greatly. And unlike in Northern Looma, the resultative/stative construction (where the $\mathrm{S}_{\mathrm{o}}$ coding is found) can only be intransitive in Kpelle.

5.1. Consonant alternation in Kpelle. The final nasal velar element responsible for the consonant alternation in SWM languages has been maintained in Kpelle in a form closest to that of Proto-SWM (while in Looma, Bandi, Loko, Zialo it has vanished, leaving behind a floating feature, and in Mende it disappeared altogether). It nasalizes subsequent sonants and sonorizes voiceless consonants; before a pause it is realized as a velar nasal $-\eta$.

5.2. The morphology of $S_{0}$ encoding. In the resultative/stative construction, the $S_{o}$ is prefixed on the verb with personal indexes (see Table 4) analogous to those in Looma. The

\footnotetext{
${ }^{25}$ Although Kpelle is probably the best documented language of the SWM group, the data on nonaccusative constructions available from published works (numerous publications by Welmers and by Westermann, a big dictionary Leidenfrost \& McKay 2007, etc.) are nevertheless very fragmentary and unsystematic. At my request, a student of mine, Maria Konoshenko, has collected the relevant data (she worked with a speaker of the Guinean variety of Kpelle, Fassou Loua); these data will be analyzed in her M.A. thesis. Unless otherwise specified, the Kpelle data in the present article stem from (Konoshenko 2011b) and from personal communication with Maria Konoshenko.
} 
verb adjoins two suffixes: $-a$ ( $-\varepsilon$ if preceded by $-e$ or $-\varepsilon$ ), the marker of the stative/resultative aspect, and $-i$, the predicativity marker $(30 \mathrm{a}, \mathrm{b})$ : 
Table 4. Personal indexes of the Guinean Kpelle

\begin{tabular}{|l|l|l|}
\hline & Singular & Plural (+3) \\
\hline 1 pers. & ý- & gǔ- \\
\hline $1+2$ pers. & & kú- \\
\hline 2 pers. & é- & ká- \\
\hline 3 pers. & ỳ- & ď̃- \\
\hline
\end{tabular}

Notes: 1SG and 3SG markers manifest themselves through the 'strong' alternation grade of the initial consonant of the head word and a modification of its initial tone. In this paper, they will be transcribed (following Konoshenko's orthography) as prefixes: ந́-lèě [néè] 'my mother', ìj-lèě [nèě] 'his/her mother', cf. é-lèě [éléè] 'your (sg.) mother'. 
(30a) ì̀-lélé-é-ì.

[nènééì]

3SG-be.beautiful-STAT-PRED

'(S)he is beautiful'.

The pronominal index is absent when the sole argument of the verb is represented by a NP:

(30b) Pépèè lélé-'-́̀-

Pepe be.beautiful-STAT-PRED

'Pepe is beautiful'.

Similarly to Looma, the past marker for the stative construction is a post-verbal auxiliary $k \grave{\varepsilon}$

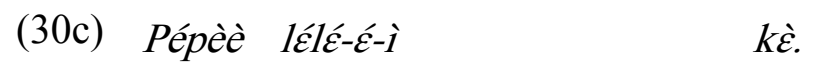

Pepe be.beautiful-STAT-PRED PST

'Pepe was beautiful'.

The negative stative/resultative construction is $\mathrm{S}_{\mathrm{a}}$-encoded by a negative pronominal auxiliary:

(30d) HWǒ lélé-li.

3SG.NEG be.beautiful-STAT

'(S)he is not beautiful'.

As in Looma, in the other aspectual constructions we find $\mathrm{S}_{\mathrm{a}}$ encoding (with pronominal auxiliaries), e.g. the resultative construction:

(30e) À̀̀ lélé.

3SG.RES be.beautiful

'(S)he has grown beautiful'. 


\subsection{Semantics of the $S_{0}$-encoded construction}

As it is demonstrated in 5.2, the only $\mathrm{S}_{0}$-encoded verbal form is that of the stativeresultative aspect marked by a double suffix $-a-i(-\varepsilon-i)$. This form cannot be used transitively, and the grammatical semantics of the construction depends very much on the Aktionsart of the verb.

- With verbs of qualitative semantics (lélé 'be beautiful', kpj̀lú 'be red', etc.) the meaning of this construction is stative/qualitative, see (30a-c).

- With verbs of processual semantics, the construction has a meaning of 'excessive action':

(31)

$\grave{\eta}-y \grave{\varepsilon} l \hat{\varepsilon}-\varepsilon-\grave{\varepsilon}$

(kéné).

3SG-laugh-STAT-PRED much

'He has much laughed'.

(32) ̇̀-n’̀ón-àà-ì.

3SG-respire-STAT-PRED

'He puffed, he respired intensively'.

- With telic verbs, the meaning of the construction is resultative (inferential semantics seems to be present as well):

(33) ̀̀-láá-ì kèá.

3SG-lie.down $\backslash$ STAT-PRED now

'He is in the bed'.

(34) ந́-lèă-á-ì Pépèè 6à.

1SG-forget-STAT-PRED Pepe DAT 
'I have forgotten about Pepe'. ${ }^{26}$

If the verb is basically transitive, the construction has a resultative and passive reading; the agent can be introduced by the postposition $6 a$ (otherwise, this postposition can also express a benefactive meaning):

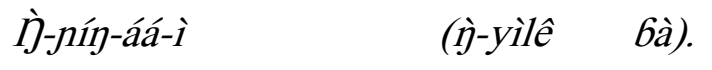

\section{SG-bite-STAT-PRED DEF-dog DAT}

'He has been bitten (by the dog)'.

Multiple readings of one and the same phrase are sometimes possible, e.g. 'passiveresultative' (a) and 'excessive' (b) in (36):

(36)

$$
\text { ந̀-tólú-á-ì ̆-bà. }
$$

3SG-call-STAT-PRED 1SG-DAT

(a) 'Pepe has been called for me'; (b) 'Pepe has been called by me many times'.

Stative/qualitative (a) and resultative-passive (b) interpretations are possible in (37):

(37) நWó Géláá gwúó-á-ì.

3SG.POSS sheep steal-STAT-PRED

(a) 'My sheep is a thief'; (b) 'My sheep has been stolen'.

From the former reading, it is possible to proceed to an antipassive interpretation of the stative/qualitative construction with the verb gwús 'steal', cf. (38a, b):

(38a) ̇ $\quad$ gwó Géláá gwúó.

3SG.BAS 1SG.POSS sheep steal

'He stole my sheep'.

${ }^{26}$ This example looks like if it is a transitive construction but genuine transitive construction put their object before the verb, as shown in Section 2.2. 
3SG-steal-STAT-PRED

'He is a thief' (litt.: 'He steals', 'Stealing is his characteristic').

The sentence (38b) could be regarded as derived from (38a) through the omission of the direct object ( Đwwó béláá 'my sheep'). However, it would be too hasty to ascribe the antipassive meaning to the stative-resultative construction, for the verb gwús seems to be an isolated case. In fact, it is one of a small number of denominative verbs ( $y w u ́ c$ 'stealing' $\rightarrow$ 'to be thief' $\rightarrow$ 'to steal'; léć 'lie' $\rightarrow$ 'to be liar'; hîâ 'contradiction' $\rightarrow$ 'to be quarrelsome'; nàlààj 'caprice' $\rightarrow$ 'to be capricious', lámánáń 'slyness' $\rightarrow$ 'to be sly') which can be used verbally in the stative-resultative construction, but not in the other aspectual constructions. In this respect, „ywús seems to be the only exception, for it seems to function as a full-fledged verb, cf. (38a).

\subsection{The nature of the verbal form in the $S_{0}$-encoded construction}

Evidently, the verbal form with the $-a-i(-\varepsilon-i)$ double suffix is a resultative participle in origin, which explains the impossibility of using it transitively: Mande languages follow the logic formulated in (Nedjalkov 1983), according to which objective resultative constructions are much more frequent in different languages than subjective ones, especially subjective resultative constructions with transitive verbs. However, in the modern language this verbal form should be considered as finite, for it is freely used as the predicate of a mononuclear sentence. 


\section{Mende. $^{27}$}

Mende is the largest language of the Southwestern Mande group spoken by about $1,900,000$ people in Sierra Leone. It resembles in many respects the Looma language, but there are at least two major differences that should be mentioned before we proceed to the Mende alignment patterns.

\subsection{Initial consonant alternation system}

Consonant alternation in Mende follows the same logic as that in Looma, with one significant difference: in Mende, the voiced plosive consonants maintain the prenasalization (which reflects the original 3SG prefix/referential article), although it tends to be weakly articulated by many speakers, see Table 5 .

${ }^{27}$ The Mende data represented here are taken from Innes' Practical Course [1971] and, to some extent, from his dictionary [1969], but the orthography is modified according to the current morphological interpretation of the data. 
Table 5. Consonant alternation in Mende (simplified)

\begin{tabular}{|l|l|l|l|l|l|l|l|l|l|l|}
\hline strong grade & $\mathrm{p}$ & $\mathrm{mb}$ & $\mathrm{t}$ & $\mathrm{nd}$ & $\mathrm{k}$ & $\mathrm{gg}$ & $\mathrm{kp}$ & $\mathrm{f}$ & $\mathrm{s}$ & $\mathrm{nj}$ \\
\hline weak grade & $\mathrm{w}$ & $\mathrm{b}$ & $\mathrm{l}$ & $\mathrm{l}$ & $\mathrm{g}, \mathrm{w}$ & $\mathrm{y}, \mathrm{w}$ & $\mathrm{gb}$ & $\mathrm{v}$ & $\mathrm{j}$ & $\mathrm{y}$ \\
\hline
\end{tabular}


However, Mende has advanced much further in the loss of the Proto-SWM word-final nasal element. In this language, no trace of this element has been preserved, not even a floating feature. As a result, within a noun phrase, the initial consonant of the second word undergoes lenition after any noun (even those which originally ended with a $\left.{ }_{-}-\eta\right)$, cf.:

ngálú wúlò 'small egg' (ngálú/yálú < Proto-SWM *ij̀-gálVy 'egg'; kúlò/gúlò wúlò 'small'), and

kwàlá wúlò ‘small monkey’ (kwàlá/gwàlá < Proto-SWM *(ì-)kwàlá ‘monkey’).

There are relics of the ancient distinction, such as the existence of two allomorphs of the indefinite plural marker (-à -ngà ) and of the perfect marker (also -à -ngà ); however, in both cases the variants are in free variation and can join any stem, independently of the

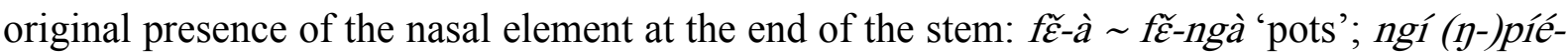
à ngí (y-)píe-ngà 'I have done it' (Innes 1971: 21, 144).

\subsection{Transcategorial personal prefixes in Mende (Table 6).}

As in Looma and other SWM languages (see Section 2.2), the Mende personal prefixes serve, first of all, to index a direct object on the verb, an oblique object on the postposition, and a nominal attribute on the noun. 
Table 6. Personal prefixes in Mende

\begin{tabular}{|c|c|c|}
\hline & Singular & Plural \\
\hline 1 & ná- & $m u-$ \\
\hline 2 & $b i^{\prime}$ & $W U-$ \\
\hline 3 human & $n g i-$ & $t i-$ \\
\hline 3 non-human & $(\eta-)$ & \\
\hline
\end{tabular}


At the same time, the personal prefixes in Mende have several interesting features distinguishing them from their counterparts in the other languages of the group. One point of divergence is that in Mende, the 3SG prefix has split into two: ngi- is a human 3SG marker, while the non-human is represented by a strong alternation grade of the initial consonant of the word. The 3SG non-human pronominal marker exerts a certain influence on the tone of the verb to which it is prefixed, although this influence is much less overt compared to the 1SG and 3SG prefixes in Looma. All other members of the same paradigm, except for the $1 \mathrm{SG}$ and $2 \mathrm{SG}$, carry a tone opposite to the tone of the subsequent word, which reveals their bound character in relation to the latter; the tone of the subsequent word remains unchanged ${ }^{28}$.

Most likely, the segmental 3SG (human) and 1SG prefixes in Mende represent an innovation. It can be easily explained by the loss of the syllabic character of the ancient prefixes $1 \mathrm{SG} *^{*} \not \dot{y}$ - and $3 \mathrm{SG}{ }^{*} \grave{j}$ - in Mende, which resulted in their substitution by 'weightier' segmental forms. However, the ancient 3SG form has been maintained (as a non-segmental morpheme) in a narrower function, namely as a 3SG non-human marker. The fact that the less marked form has been kept for the non-human pronominal marker fits perfectly with the wellknown ontological principle in linguistic typology that "nouns for animate participants, especially for humans, gravitate to the position of subject, while inanimate nouns are attracted to the position of direct object" (Kibrik 2003: 120). The less marked (non-segmental) form designates the more usual situation, while the 'heavier' segmental form is reserved for the less frequent one. ${ }^{29}$

\footnotetext{
${ }^{28}$ Cf. Creissels' analysis of the object markers in Mende as bound morphemes in (Creissels 2005: $53)$.

${ }^{29}$ The 'human/non-human' pronominal split, which is very rare in the Mande family and is clearly a Mende innovation, has extended to the 'instrumental' pronominal set used with the preposition $\grave{a}$ (these pronouns should probably be regarded as bound forms, otherwise it would be difficult to represent the set as a single paradigm including the 3SG non-human form là):
} 
Pronominal predicative markers are represented by several sets.

Table 7. Instrumental pronouns in Mende

\begin{tabular}{|l|c|c|}
\hline & Singular & Plural \\
\hline 1 & $\grave{a}$-ngé & à-mùé \\
\hline 2 & $\grave{a}$-bíé & à-Wùé \\
\cline { 1 - 2 } 3 human & à-ngìé & à-tié \\
\cline { 1 - 2 } 3 non-human & là & \\
\hline
\end{tabular}


Table 8. Pronominal auxiliaries in verbal sentences in Mende

\begin{tabular}{|c|c|c|c|c|c|c|c|}
\hline & \multicolumn{3}{|c|}{ Singular } & \multirow{2}{*}{$\begin{array}{c}\text { Dual } \\
1+2\end{array}$} & \multicolumn{3}{|c|}{ Plural } \\
\hline & 1 & 2 & 3 & & 1 & 2 & 3 \\
\hline Basic & ngí & bí & $i / \varnothing$ & - & $m u ́$ & $w u ́$ & $t i ́$ \\
\hline Future/Habitual & ngá & bá & $\grave{a}$ & - & má múá & wá wúá & tá \\
\hline Optative ('subjunctive') & ngí & bí & $i$ & $m u ́$ & àmú & wú & $t i ́$ \\
\hline Negative & $n g \hat{1}$ & bî̀ & $\dddot{\imath i}$ & - & múì & wúi & $t \hat{\imath}$ \\
\hline Prohibitive & ngàá & bàá & àá & - & màá & Wàá & tàá \\
\hline Negative Future/Habitual & $n g \varepsilon^{\prime} \dot{\varepsilon}$ & $b \varepsilon^{\prime} \dot{\varepsilon}$ & $\grave{\varepsilon} \grave{\varepsilon}$ & - & múc̀ & wúc̀ & $t \varepsilon \dot{\varepsilon}$ \\
\hline
\end{tabular}


In the Basic set, the zero allomorph appears when the subject position is non-null, and $i$ is used in null-subject sentences. ${ }^{30}$

As we can see, all the sets of pronominal auxiliaries (Table 8) can be easily distinguished from the pronominal prefixes either on the segmental or on the suprasegmental level.

\subsection{The S-split in Mende}

Just as in the SWM languages analyzed above, the sole argument of qualitative verbs is marked in Mende by a pronominal prefix, rather than by a pronominal auxiliary. The verb appears in the qualitative construction in a '-ngj-form', which will be referred to as a gerundive (for it assumes both adjective-like and noun-like usages):

(39a) ( -)Kútú-ngò.

3SG.NHUM-short-GER

'It is short'.

(39b) Tì-gútú-ngò.

3PL-short-GER

'They are short'.

When the sole argument is expressed by a non-null NP, the pronominal prefix is absent:

(40) Màhè-í wówá-ngj̀.

chief-DEF be.old-GER

'The chief is old' (ngóvá/wóvá 'to be old').

${ }^{30}$ Creissels (2005: 47) treats the 'subject markers' as bound morphemes (clitics?) attached to the first word of the verb phrase. However, these markers do not display the characteristics that one would expect from clitics (such as tonal or segmental accommodation) and, to my mind, they should be regarded as autonomous forms (contrary to Innes' interpretation, not as 'subject pronouns', but rather as pronominal auxiliaries). 
The gerundive nature of the $-n g \grave{\jmath}$-form is confirmed by the following evidence. Innes mentions (1971: 112) that the -ngj-form can be followed by the element -é (presumably a suffix). In this case, the construction sounds 'somewhat more emphatic': ngí-nàndé-ngò-é 'She is pretty'. He supposes that this element might originate from a copula (in his terminology, 'particle’) lé. Sengova (1981: 84) endorses this interpretation: “/ngذ̀/ ... may be followed by /lé/, such that they are contracted in speech as ngò'è, /lè/ having lost its initial consonant". The data from the Bandi language, where the stative construction includes a gerundive form (with the suffix $-n g j$ ) and a copula -le, can also be interpreted in favor of this supposition.

A gerundive form can be used in nominal (41) and adjectival (42) functions as well: (41) I

$$
\text { ná-ló-ì-lò ngì-lí-ngò-í hù. }
$$

3SG.BAS 1SG-see-PST-FOC 3SG.HUM-go-GER-DEF in

'He saw me as he was going' (Innes 1971: 184).

(42)

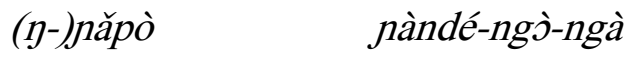

REF-young.woman pretty-GER-PL.INDEF

'pretty young women'.

A qualitative verb can also appear in the other verbal constructions in its inchoative meaning. In such casees, it follows the nominative/accusative morphological model: its sole argument is $\mathrm{S}_{\mathrm{a}}$-coded (i. e., it is expressed by a pronominal auxiliary), see (43).

jàndè-1́-1’̀

3SG.BAS be.pretty-PST-FOC

'She became pretty' (Innes 1971: 135). 
There are two types of negative constructions for the qualitative verbs. One of them (which is less frequent) is derived from the affirmative construction by the negative marker ii and the obligatory copula lé:

\section{(44) Ngí-nàndé-ngò iì lé 3SG-pretty-GER NEG COP \\ 'She is not pretty'.}

The other option, just as in other SWM languages, is to use the regular negative past verbal construction (the negative pronominal auxiliary, with the verb joined by the suffix $-n i$ ), which follows the nominative/accusative strategy:

(45) Iì Wòwà-nì.

3SG.NEG be.old-PST

'He/she/it is not old'. ${ }^{31}$

In Mende (unlike in Liberian Looma) non-qualitative verbs can also appear in the qualitative construction. In this case, they express stative or resultative meaning. However (unlike in Kpelle or in Northern Looma) the sole argument of the verb in such a construction can fulfill only non-active semantic roles, such as patient $(46,47)$ or experiencer $(48)$ :

(y-)Kpòyó-ngò.

3SG.NHUM-finish-GER

'It is finished'.

${ }^{31}$ There is a homonymy of the 3 SG.NEG pronominal auxiliary and the negative copula, both being represented by the form iì. However, their syntax is different, which prevents them from becoming confused. 
(47)

Ná-hègbé-ngò yèlé.

1SG-be.ill-GER PST

'I was ill'.

(48) Ngì-lóló-ngò à̀-ngé.

3SG.HUM-hate-GER with-1SG

'He is jealous of me', 'He hates me' (Innes 1971: 158).

The polysemous verbs that allow both agentive and non-agentive subjects can be used in the -ngò-construction only when a non-active role is attributed to the argument. For instance, the verb ndá/lá follows the nominative/accusative $\left(\mathrm{S}_{\mathrm{a}}\right)$ pattern when it means 'to lie down' (49a), and the active/stative $\left(S_{o}\right)$ pattern when its meaning is stative, 'to believe' (49b):

(49a) Táá lá-má.

3SG.FOC lie.down-PROG

'He is lying down'.

(49b) Ná-lá-ngò à ná.

1SG-lie.down-GER with that

'I believe that'.

The same is true for the verb kpiá/gbiá : the nominative/accusative strategy is compatible with dynamic meanings ('to go out; to take out, to remove'), whereas the active/stative strategy is reserved for the stative meaning 'to resemble' (50):

(50) Ngí-gbìá-ngò à ngí-njè.

3SG.HUM-come.out-GER with 3SG.HUM-mother

'She resembles her mother' (Innes 1971: 157). 
The -ng̀-form of a verb appears in a temporal clause with the meaning of precedence or simultaneity. In such contexts, verbs with a sole active argument are allowed:

(y-)Màhè-í hèr-ngò-ó kè mù-gbí mú hèríngà.

REF-chief-DEF sit-GER-? and 1PL-all 1PL.BAS sit-PRF

'The chief being seated, then we all sat down' (Innes 1971: 185).

Mathew Sengowa mentions that the $-n g \hat{j}$-form in a temporal clause most frequently carries the definite article $-i$ and is usually followed by the demonstrative pronoun $j i$ ' this' or the postposition $h \grave{\sim}$ 'in':

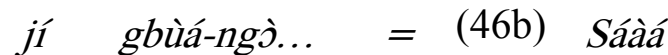

jí gbùá-ngò-í

jí...

sacrifice this remove-GER = sacrifice this remove-GER-DEF this 'Upon the completion of this ritual sacrifice...' (Sengowa 1981: 194).

In other words, the $-n g \grave{j}$-form in a temporal clause is nominalized to a certain degree.

\section{The thematic role of the $S_{0}$ in Liberian Looma}

As Arkadiev (2008: 112) stated in respect of Liberian Looma, "Loma ... is not a 'typical' semantically aligned language, since the 'split' in argument marking is here conditioned solely by the aspectual property "stativity". It is true that $\mathrm{S}_{\mathrm{o}}$ encoding manifests itself in all the SWM languages in one aspectual type only, namely the stative/resultative/perfect. However, to my mind, this statement concerning the aspectual-conditioned nature of the Ssplit needs at least two serious amendments.

Firstly, the term 'stative verbs' (see the list for Liberian Looma at the beginning of Section 3) is not quite accurate: these verbs designate inherent properties, while temporary 
states are expressed by a $\mathrm{S}_{\mathrm{a}}$ construction with 'dynamic verbs' (é zéi-ni 'he is sitting') ${ }^{32}$. Evidently, for the 'stative verbs', their use in $\mathrm{S}_{0}$-constructions is prototypical, and their conversion into 'dynamic verbs' (with the meaning of 'coming into a state/quality') and use in $\mathrm{S}_{\mathrm{a}}$-constructions is secondary. It should be emphasized that not every verb in Liberian Looma can be used in the 'stative' (more precisely, 'qualitative') construction; this ability is reserved for verbs of qualitative semantics belonging to a closed list. Therefore, the S-split in this language variety cannot be reduced to an aspectual opposition (if by 'aspect' we mean an inflectional grammatical category); it is undoubtedly of a lexical semantic nature.

Secondly, a question concerning the semantic role of the sole argument of a qualitative verb arises. It can hardly be identified with the Patient, since typically patientive verbs (such as páa 'die', tò 'fall', sólo(ฤ) ‘be born') do not belong to our list, and it is certainly outside the scope of the Proto-Patient in Dowty's (1991) sense ${ }^{33}$. Its semantic role could be defined as 'Holder of a Property', and the split intransitivity in Liberian Looma should be recognized as semantic role-related, rather than aspect-related.

The 'Holder of a Property' semantic role for sole $S_{0}$ arguments is common to all the SWM languages. Generalization of this role, among other things, facilitated the verbalization of the Kpelle nouns mentioned in 5.2 (léć 'lie' $\rightarrow$ 'to be liar'; hîa 'contradiction' $\rightarrow$ 'to be quarrelsome', etc.).

\section{On the origin of the $S_{0}$ constructions in SWM}

\footnotetext{
${ }^{32}$ The semantic difference between the so-called 'static' and 'dynamic' verbs in Looma is exactly what Mithun (1991) means by 'affectedness', which is certainly a semantic feature.

${ }^{33}$ Arkadiev (2008) summarizes Dowty's Proto-Patient characteristics as follows: A Proto-Patient (a) undergoes a change of state; (b) is an incremental theme; (c) is causally affected by another participant, and (d) is stationary relative to the movement of another participant.
} 
The emergence of the non-accusative morphological features in SWM may seem eccentric, taking into account their extreme rarity in Africa. However, the predisposition of Mande languages to non-accusativity (although rather obscure, because of the paucity of morphology in the best studied languages of the family) is a known fact: see, for example, a discussion of the patient-oriented nature of Manding in (Tröbs 2009: 260-265), and Creissels' (1997a, 1997b) hypothesis concerning the origin of the perfective affirmative auxiliary in Manding from an ergative-like construction.

It can be observed that the evolution towards non-accusativity (and, in particular, to semantic alignment) in SWM goes hand in hand with the acquisition of head-marking morphology, in line with the well-known fact that semantically aligned languages tend to be head-marked (Nichols 1992: 100-102; Wichmann 2008: 21). In SWM, the pronominal indexes on the stative verbs are identical with the pronominal indexes on postpositions and on head nouns in the NPs, see ex. (1-11) above, and the morphologization of the pronominal series in question (as well as the emergence of the non-accusative features) apparently dates back to the Proto-SWM period ${ }^{34}$.

\subsection{Non-accusative morphology}

$\mathrm{S}_{0}$-constructions with a 'stative' (more precisely, 'qualitative') verb, suffixless or provided with a participial or gerundive suffix, are attested in all the languages of the group. Let us scrutinize them.

\section{Present stative in Looma}

A probable source of the affirmative stative suffix in Looma is the presentative copula, cf.: Folomo vè. 'It is Folomo'; Gálá(ク) bé. 'It is God'. A construction of the structure 'Noun + Adjective or Participle + presentative copula' is failry typical of the Mande languages, and it

\footnotetext{
${ }^{34}$ Which is not very remote: according to glottochronology, the proto-SWM split took place a little less than 2000 years ago (Vydrin 2009).
} 
might have served diachronically as a model for the stative/qualitative construction in Looma, cf. in $\mathrm{Mwan}^{35}$ :

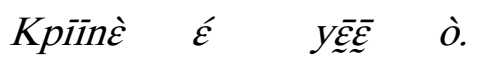

eggplant ART bitter COP

'The eggplant is bitter'.

Cf. in Bamana:

(54) $\grave{A}$ sigi-len bé.

3SG sit-PTP COP

'He is sitting'.

One can assume that the current stative construction may stem from a construction with a predicative adjective followed by a copula, and the fusion of the adjective with the copula led to the integration of the resulting form into the verbal system.

However, contrary to what was said in (Vydrin 1987: 47), it would be erroneous to merely identify the stative/qualitative marker with the copula in the modern Looma. This becomes obvious if we compare their forms by dialect, see Table 9:

\footnotetext{
${ }^{35}$ Example by Elena Perekhvalskaya (personal communication).
} 
Table 9

\begin{tabular}{|c|c|c|}
\hline & copula & stative suffix \\
\hline Liberian Gizima (Sadler 1949/2006) & be/ve & $-\varepsilon /-V \varepsilon$ \\
\hline Wubomai, Wode (Heydorn 1971) & bé/vé & $-\varepsilon /-V \varepsilon$ \\
\hline Koima (Wilhoit 1999) & $b e / ß e$ & $-\varepsilon /-\beta e$ \\
\hline Woi-Balagha (Mishchenko 2009) & bè/ßè & 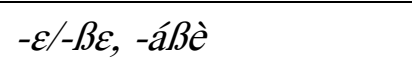 \\
\hline Vekema (Vydrin 1987) & $b \varepsilon / \beta \varepsilon($ or $b e / ß e ?)$ & $? /-\beta \varepsilon \sim-1 e$ \\
\hline Luloma (Prost 1967) & $b e / v e$ & -dave $\sim$-ave $\sim-v e /-a v e$ \\
\hline
\end{tabular}

\footnotetext{
${ }^{36}$ In Heydorn's data, no opposition between $v$ and $\beta$ is attested.
} 
The major point of difference (apart from the vocalic variation among the dialects) is the irregular allomorph of the stative suffix $-\varepsilon$ (instead of $*_{-} b \varepsilon$ as one might expect) that appears with stems ending in the floating nasal element (cf. example (14)). This irregularity is a manifestation of the advanced degree of grammaticalization and morphologization of the marker.

\section{Past Stative in Looma.}

Forms of the Past Stative vary among the Looma dialects. Unfortunately, I have no data for the Wubomai and Bode dialects, so let us consider what is available.

Sadler produces a form ending in -ai (cf. examples $17 \mathrm{a}, \mathrm{b}$ ) and mentions that it is a combination of the 'recent past' suffix $-a$ and the 'definite suffix' $-i$; the $-a i$-form is normally followed by the copula $\gamma \varepsilon \mathcal{\varepsilon}$ (undoubtedly, this $\gamma^{\varepsilon}$ is etymologically identical with the Kpelle post-verbal auxiliary $k \dot{\varepsilon}$ mentioned in 5.2, cf. ex. (30c)). The same suffix is attested in Vekema (Vydrin 1987: 49-50).

For Koima, Wilhoit (1999) mentions two forms: 'Perfect Stative' -aße (in the independent clauses) and 'Definite Perfect' - ai (in the dependent clauses). Unfortunately, she provides no example sentence with these forms ${ }^{37}$.

According to Prost (1967: 87), the past stative is expressed by the suffix $-n i$ :

$$
\text { (í-)Seye-i teig-e wole-ni, kele é nowo-a. }
$$

REF-clothing-DEF this-SBJ be.white-PST but 3SG.BAS dirty-PRF

'This clothing was white, but it has got dirty'.

\footnotetext{
${ }^{37}$ Wilhoit also mentions a 'Locative Imperfective' form marked with the suffix $-s u ß \varepsilon /-z u ß \varepsilon$ which is indexed by the personal prefixes for the subject (and therefore follows a Active/Stative or Ergative strategy), but, unfortunately, no other information on this construction is available.
} 
This author provides no examples with a $1 \mathrm{SG}$ or $3 \mathrm{SG}$ pronominalized (or null) subject that would be diagnostic for the Nominative/Accusative or Active/Stative strategies. However, the ending $-e$ of the subject NP is indicative of the Nominative/Accusative morphology of this construction. In Woi-Balagha, the past stative is also marked by the suffix $-n i$ on the verb, whose argument-marking follows the Nominative/Accusative pattern and whose sole argument is marked by the Basic series of the auxiliaries (Daria Mishchenko, personal communication).

Therefore, the past stative forms everywhere (with the exemption of the Northern Looma dialects) are formed with the suffix $-a$, which might be identical with the marker of the Perfect and resultative participle (or gerund?). If this assumption is true, the Past Stative construction can be interpreted as belonging (at least etymologically) to the same type as the Present Stative one (Noun + Participle + copula) analyzed above.

\section{Stative/resultative constructions in Bandi, Mende and Proto-SWM}

The origin of the stative/resultative construction in Bandi follows the same logic (gerund + copula) as in Looma, and the same model can be easily reconstructed for Mende. It is a case of structural similarity, rather than material one: stative verbs in Looma have no suffix, while their Bandi and Mende counterparts have the gerund suffix $-n g$; in Looma, the copula might have been *be, while in Bande and Mende, it is le. Therefore, we can reconstruct a stative (or stative/resultative) construction with S-split alignment for the Proto-SWM level, but it is not quite clear which verbal marker and copula were used in this construction ${ }^{38}$.

${ }^{38}$ There are however some indications which might be interpreted in favor of pre-existence in Looma of a suffix $-g o$ or $-\supset$ (a cognate of the Mende and Bandi suffix $-n g o$ ) used with qualitative verbs. So, the verb $p a(\eta)$ 'be good, be beautiful' appears in some contexts in the form pago. Therefore, a verbal form with the suffix $-g o$ or $-\supset$ in the stative/resultative construction in Proto-SWM is plausible. 


\subsection{Evolution of the semantics of the $S_{0}$-constructions}

It turns out that all the SWM languages have a $\mathrm{S}_{0}$-coded construction with 'stative' (more precisely, qualitative) verbs, and the same situation can be therefore reconstructed for ProtoSWM. The Liberian Looma situation is therefore the closest to the primitive one.

The other instances of the use of the $\mathrm{S}_{\mathrm{o}}$ construction vary from one language to another and should be regarded as innovations.

In Kpelle, $\mathrm{S}_{\mathrm{o}}$ encoding has spread to the constructions with dynamic verbs, thus eroding the semantic basis of the S-split. To the extent that the 'Holder of a Property' role was incompatible with the semantics of the dynamic verbs, adjacent semantic roles were put into play: a Patient in the resultative construction (since the resultative meaning is close to stative), and, on the other hand, the Actor of an iterative action (for the iterative meaning is a natural projection of the stative or processual meaning on the verbs of punctive lexical semantics); the iterative semantics has quite naturally evolved into an intensive meaning. The semantic alignment has transformed into an aspect-split ergativity.

In Northern Looma, the evolution might have been similar to Kpelle, but went a little bit further with respect to the integration of the resultative/stative construction into the aspectual system: in Kpelle it is somehow marginal because of its incompatibility with transitive verbs (or the transitive uses of labile verbs), but in Northern Looma this restriction has vanished.

In Mende, unlike in Liberian Looma, the $\mathrm{S}_{\mathrm{o}}$-verbs do not represent a closed class any more. Unlike in Northern Looma and Kpelle, the spread of the $\mathrm{S}_{0}$-construction was semantically conditioned: the $\mathrm{S}_{0}$-encoding on the verb is conditioned by its stative or qualitative meaning. Therefore, we have in Mende a semantically (rather than lexically) conditioned S-split; otherwise, the situation is close to that in Liberian Looma. 


\section{Conclusion}

The SWM languages seem to follow the scenario of emergence of semantic alignment described by Danielsen and Granadillo (2008) for two Arawak languages: the argument coding associated with inherently stative parts of speech, such as nouns, adjectives and/or non-finite verbal forms spread to the verbal sphere when these forms acquired verbal uses; these verbs have stative/qualitative semantics ${ }^{39}$. At the subsequent stage (in Kpelle and Northern Looma), this encoding extended to all the intransitive verbs with the resultative and/or intensive constructions, so that the semantic alignment is replaced by aspectual alignment' (a split-ergative system).

The logic of the emergence of Northern Looma syncretism can be traded, in general, as follows.

Stage 1: Any verbal subject is encoded by pronominal auxiliaries. Pronominal prefixes (encoding any NP other than subjective) index the determined noun on adjectives (and, probably, participles) used in their secondary predicative (or even attributive) function.

Stage 2. Adjectives develop a primary predicative function, thus transforming into predicative adjectives/qualitative verbs. The only argument of such a qualitative verb (in the semantic role of 'Holder of a Feature') is indexed on the verb with a pronominal prefix. This situation is observed in Liberian Looma and Bandi.

Stage 3. The prefix-indexing expands onto the predicative participial constructions with resultative meaning.

Stage 4. The participial resultative construction is reinterpreted as a true verbal one. Polysemy of this construction develops; the construction grows accessible to any verb,

${ }^{39}$ Cf. Trask's (1979) 'Type B' ergative languages, which emerged from the reanalysis of adjectival and perfective constructions that show tense-aspect splits, as opposed to the 'Type A' languages resulting from reanalysis of passive constructions for which the tense-aspect split is atypical. 
independent of its lexical semantics. The sole argument in this construction is prefix-indexed on the verb. This is the situation in Kpelle.

Stage 5. The resultative construction acquires transitive usages where the subject is encoded on the pronominal auxiliary, while in the intransitive construction it is prefix-indexed on the verb. This is the situation in Northern Looma.

\section{Abbreviations}

A subject of a transitive verb

ART article

ASS.PL associative plural

AUT autonomous pronoun

AUX auxiliary

BAS 'basic' set of pronominal predicative markers

COP copula

DAT dative

DEF definite

FOC focalization

FUT future

GER gerund

HAB habitual

HUM human

INDEF indefinite

IPFV imperfective

LOC marker for locative form of a noun

NEG negation, negative 


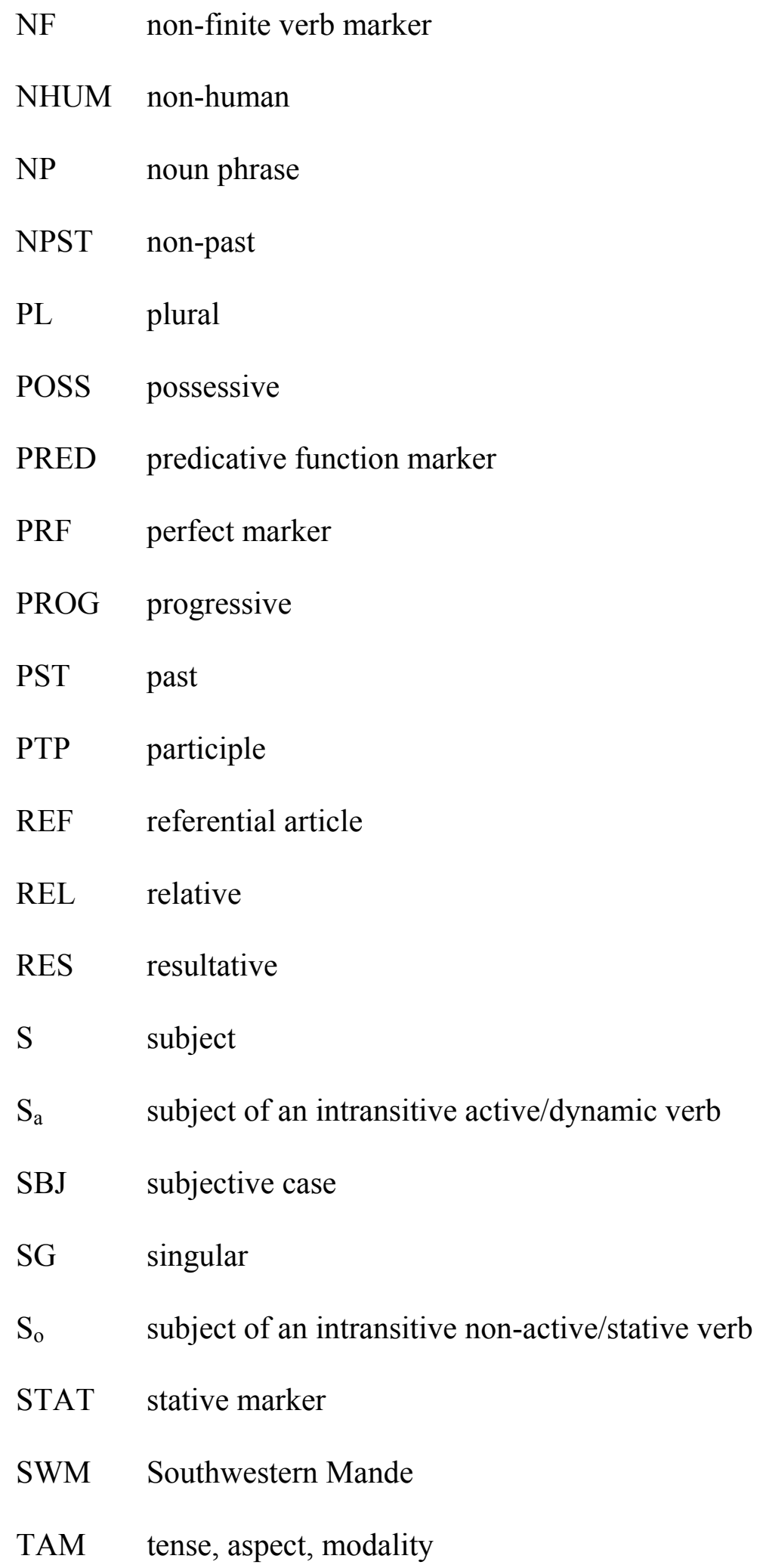

\section{References}

Anon. n.d. A Bandi Grammar. Unpublished Manuscript. Monrovia: The Institute for Liberian languages. 
Arkadiev, Peter M. 2008. Thematic roles, event structure, and argument encoding in semantically aligned languages. The typology of semantic alignment. Mark Donohue \& Søren Wichmann (eds.), 101-117. Oxford: Oxford University Press.

Babaev, Kirill. 2010. Person marking in South-West Mande languages: a tentative reconstruction. Mandenkan 46: 3-48.

Bickel, Baltasar \& Johanna Nichols. 2009. The Oxford handbook of case. Andrej Malchukov \& Andrew Spenser (eds.), 304-321. Oxford: Oxford University Press.

Creissels, Denis. 1997a. Une tentative d'explication de particularités typologiques de la négation en mandingue. Mandenkan 32: 3-21.

Creissels, Denis. 1997b. Postpositions as a possible origin of certain predicative markers in Mande. Afrikanistische Arbeitspapiere 50: 5-17.

Creissels, Denis. 2005. A typology of subject and object markers in African languages. Studies in African linguistic typology. Erhard Friedrich \& Karl Voeltz (eds.), 43-70. Amsterdam: John Benjamins.

Danielsen, Swintha \& Granadillo, Tania. 2008. Agreement in Two Arawak Languages: Baure and Kurripako. The typology of semantic alignment. Mark Donohue \& Søren Wichmann (eds.), 396-412. Oxford: Oxford University Press.

Dixon, Robert M.W. 1994. Ergativity.. Cambridge: Cambridge University Press. [Cambridge Studies in Linguistics; 69].

Donohue, Mark. 2008. Semantic alignment systems: what's what, and what's not. The typology of semantic alignment. Mark Donohue \& Søren Wichmann (eds.), 24-75. Oxford: Oxford University Press.

Dowty, David R. 1991. Thematic proto-roles and argument selection. Language 67(3): 547619. 
Dwyer, David. 1973. The comparative tonology of Southwestern Mande nominals. PhD Diss. Michigan State University.

Dwyer, David \& Bodegie, P. \& Baque, A. 1981. A Reference Handbook of Lorma. East Lansing: African Studies Center, Michigan State University.

Hachaturyan, Maria. 2010. The syntactic approach to pronominal systems in South and South-Western Mande languages. Personal pronouns in Niger-Congo languages: International workshop. St. Petersburg, September 13-15, 2010. Abstracts and papers: Working materials. Konstantin Pozdniakov, Valentin Vydrin, Alexander Zheltov (eds.): 42-47. St. Petersburg: St. Petersburg University Press.

Heydorn, Richard.W. 1940-1941. Die Sprache der Bandi in nordwestlichen Liberia. Zeitschrift für Eingeborenen-Sprachen 31 (2): 81-114, 31 (3): 188-217.

Heydorn, Richard W. 1971. Grammar of the Loma Language with some Kons Words in the Vocabulary. Afrika und Übersee 54 (1/2): 77-99.

Innes, Gordon. 1969. A Mende-English dictionary. Cambridge: Cambridge University Press. Innes, Gordon. 1971. A Practical Introduction to Mende. London: SOAS.

Kibrik, Alexandre E. 1997. Beyond subject and object: Toward a comprehensive relational typology. Linguistic Typology 1 (3): 279-346.

Kibrik, Alexandre E. 2003. Konstanty i peremennye jazyka (Constants and variables of language). St. Petersburg: Aleteia.

König, Christa. 2005. Case in Africa: On categorial misbehavior. Studies in African linguistic typology. Erhard Friedrich \& Karl Voeltz (eds.), 195-207. Amsterdam-Philadelphia: John Benjamins.

König, Christa. 2009. Marked Nominatives. The Oxford handbook of case. Andrej Malchukov \& Andrew Spenser (eds.). 533-548. Oxford: Oxford University Press. 
Konoshenko, Maria. 2011a. Tonal'nye sistemy dialektov jazyka kpelle. Trudy Instituta lingvisticheskikh issledovanij. [Tonal systems of Kpelle dialects. Transcasctions of the Institute of linguistic studies.]. St. Petersburg. (in press).

Konoshenko, Maria. 2011b. Bazovyje grammaticheskie kategorii gvinejskogo kpelle. [Major grammatical categories of the Guinean Kpelle). M.A.Thesis. St. Petersburg State University.

Leidenfrost, Theodore E. \& McKay, John S. 2007. Kpelle - English dictionary with a grammar sketch and English-Kpelle finder list. Moscow (USA).

Malchukov, Andrej. Split intransitives, experiencer objects, and 'transimpersonal' constructions: (re-)establishing the connection. The typology of semantic alignment. Mark Donohue \& Søren Wichmann (eds.), 76-100. Oxford: Oxford University Press.

Mishchenko, Daria. 2009. Tonal system of Looma language: The Woi-Balagha dialect. Mandenkan 45: 3-16.

Mishchenko, Daria. 2010. Pronominal system of the Looma language: the Woi-Balagha dialect. Personal pronouns in Niger-Congo languages: International workshop. St. Petersburg, September 13-15, 2010. Abstracts and papers: Working materials. Konstantin Pozdniakov, Valentin Vydrin, Alexander Zheltov (eds.): 97-105. St. Petersburg: St. Petersburg University Press St. Petersburg: St. Petersburg University Press

Mishchenko, Daria. Ms. Looma-Russian-English-French Dictionary (Woi-Balagha dialect). Mithun, Marianne. 1991. Active/agentive case marking and its motivations. Language 67(3): $510-546$.

Mithun, Marianne. 2008. The emergence of agentive systems in core argument marking. The typology of semantic alignment. Mark Donohue \& Søren Wichmann (eds.), 297-333. Oxford: Oxford University Press.

Nedjalkov, Vladimir P. (ed.) Tipologija resultativnyh konstrukcij. Léningrad: Nauka, 1983. 
Nichols, Johanna. 1992. Linguistic diversity in space and time. Chicago: University of Chicago Press.

Nichols, Johanna. 2008. Why are stative-active languages rare in Eurasia? A typological perspective on split-subject marking. The typology of semantic alignment. Mark Donohue \& Søren Wichmann (eds.), 121-139. Oxford: Oxford University Press.

Nikitina, Tatiana. 2009b. The syntax of PPs in Wan, an "SOVX" language. Studies in Language 33(4): 907-930.

Rude, Noel. 1983. Ergativity, and the Active-Stative Typology in Loma. Studies in African Linguistics 14 (3): 265-283.

Sadler, Wesley L. 1949/2006. A complete analysis of the Looma language, Interior Liberia, West Africa. Mandenkan 42.

Sengova, Mathew J. 1981 A classification of tense, aspect, and time specification in the verb system of Mende. Ph.D. Diss., University of Wisconsin, Madison. Ann Arbor (Michigan).

Trask, Robert L. 1979. On the origin of ergativity. Ergativity: Toward a theory of grammatical relations. F. Plank (ed.): 385-406. London: Academic Press.

Tröbs, Holger. 2009. Sprachtypologie, TAM-Systeme und historische Syntax im Manding (West-Mande). Köln: Rüdiger Köppe Verlag.

Vydrin, Valentin. 1987. Jazyk looma. (The Looma language). Moscow: Nauka Publishers.

Vydrine, Valentin. 1989a. Tonal system of Looma language. Mandenkan 18: 81-96.

Vydrin, Valentin. 1989b. Reflection of the nominal classification in Manden and SouthWestern Mande: the classification category. Zeitschrift für Phonetik, Sprachwissenschaft und Kommunikationsforschung 92(1): 90-101. http://mandelang.kunstkamera.ru/files/mandelang/zpsk41.pdf

Vydrine, Valentin. 1999. Les parties du discours en bambara: un essai de bilan. Mandenkan 35: 72-93. 
Vydrin, Valentin. 2006. K rekonstruktsii fonologicheskogo tipa i imennoj morfologii pramande. Trudy Instituta lingvisticheskikh issledovanij. 2(2): 3-246. [Toward the reconstruction of the phonological type and the noun morphology of Proto-Mande. Transcasctions of the Institute of linguistic studies. 2(2)]: 3-246. St. Petersburg: Nauka.

Vydrin, Valentin. 2009. On the problem of the Proto-Mande homeland. Вопросы языкового pодства - Journal of Language Relationship 1: 107-142.

Vydrin, Valentin. 2010. Jescho raz o 'subjektnykh mestoimeniyakh' v juzhnykh mande: mestoimenija ili predikativnyje pokazateli? Osnov afrikanskogo jazykoznanija: Sintaksis imennykh grupp. [Once more about the 'subjective pronouns' in South Mande languages: Pronouns or predicative markers? Fundamentals of the African linguistics: Syntax of noun and verbal phrases.] V. A. Vinogradov (ed.): 385-400. Moscow: Academia.

Wichmann, Søren. 2008. The study of semantic alignment: retrospect and state of the art. The typology of semantic alignment. Mark Donohue \& Søren Wichmann (eds.), 3-23. Oxford: Oxford University Press.

Zheltov, Alexandre. Jazyki niger-kongo: strukturno-dinamicheskaja tipologija (Niger-Congo languages: A structural-dynamic typology). St. Petersburg: St. Petersburg State University Publishers. 